\title{
Can Ethical Leaders Heal The Wounds? An Empirical Research
}

\author{
Ufuk BASAR ${ }^{*}$, Berrin FILIZOZ**
}

\begin{abstract}
Leaders form the character and the nature of the organizations. In this respect ethical leaders may be the solution for organizations in corruption and employees in trouble. For this reason we treated ethical leadership as a healer, and analyzed its effects on intention to quit along with moderation effect of perceptions of organizational politics and mediation effect of organizational identification on this interaction. To that end, data were collected from 103 sales persons, who work at an international white good producing firm, in Ankara, Turkey through questionnaire. The data were analyzed with multifarious statistical techniques. The findings affirm healing effect of ethical leadership on intention to quit. In addition, as a new discovery, moderation effect of perceptions of organizational politics on healing effect of ethical leadership was found. Finally it was discovered that organizational identification and ethical leadership predict intention to quit separately.
\end{abstract}

Keywords: Ethical Leadership, Perceptions of Organizational Politics, Organizational Identification, Moderation, Mediation

JEL Code Classification: D23, M12

UDC: 005.7

\footnotetext{
*Doctoral Student in Business Administration, Baskent University, Turkey.

E-mail:ufuk-basar@hotmail.com

As* Assoc. Prof. of Management, Cumhuriyet University, Turkey. E-mail:bfilizoz@cumhuriyet.edu.tr 


\section{Introduction}

Recent crises in management of organizations throughout the world (Enron, World.com, Adelphia, Tyco, etc.) frequently arise from lack of leadership capabilities, which constitute the unique source of organizational culture (Trevino et al., 2003: 6; Aydemir \& Egilmez, 2010: 72). In general, employees are in need of guidance in order to act properly and work effectively. Therefore leaders should lift the baton (Brown et al., 2005: 117). The notion of leadership refers to the capacity to lead. However, in essence, it is a complex conception, which comprises several behavioral and value based competencies (Buell, 2012: 19), by which leaders influence, motivate and enable others to work for shared goals, contribute toward the effectiveness and success of the organizations and teams of which they are members (McShane \& Glinow, 2009: 231; Ford \& Ismail, 2008: 136). Among several leaders, who behave idiosyncratically, ethical leaders come forward by their virtuous characters. Ethical leaders are perceived by employees and scholars as life buoys of ailing organizations (Howell \& Avolio, 1992: 43). In a world of bankruptcies due to unethical conduct, by comprehending the prominence of ethical leadership, practitioners began to hire and develop ethical leaders and researchers conducted studies for understanding the fundamentals of ethical leadership (Brown \& Trevino, 2006: 595).

According to the findings of previous studies ethical leadership positively and negatively influences several employee outcomes (Jordan et al., 2013: 661). However, there are still a good many of questions, waiting for to be answered. Can ethical leaders heal the wounds of employees, who intent to quit job and walk out of their organizations? How employees' perceptions of organizational politics affect them? Can ethical leadership be a cure for organizational politics? Do ethical leaders cause their followers to identify themselves with their organization? Given these unanswered questions and undeniable significance of ethical leadership in the life cycle of organizations and retention of employees, this research aimed to find out the role of ethical leadership in employees' intention to quit empirically. Meanwhile how employees' perceptions of organizational politics moderates and how employees' organizational identification mediates the effects of ethical leadership on employees' intention to quit are sought as well. To that end, initially the dawn of the ethical leadership is described and theoretical interactions between ethical leadership, perceptions of organizational politics, intention to quit and organizational identification are explained. Following that research design and methodology are explicated. Finally findings are discussed and implications are emphasized. According to the findings of this research ethical leadership has a negative predictive effect on intention to quit. In addition, as a new discovery, perceptions of organizational politics moderate predicting effect of ethical leadership on intention to quit negatively. Finally it was discovered that organizational identification and ethical leadership predict intention to quit separately. 


\section{The Dawn of the Ethical Leadership}

The ethical dimension of the leadership mattered following the studies on charismatic or transformational leadership. First of all Burns (1978) emphasized the moral aspect of leadership when he defined the transforming leaders as the ones who align their own and their followers' values toward moral principles (Brown et al., 2005: 118). Drawing on the work of Burns (1978), Bass (1985) described transformational leaders as the ones who can transform followers to go beyond their self-interests by motivating them for shared ideals, interests, values and goals (Keskes, 2014: 29). According to Bass (1990: 21) transformational leadership occurs when leaders can broaden and elevate their employees' interests, incite them to look beyond their own self-interest and work for the good of the group, create a unity among group members and acceptance of the shared purposes around the mission of the organization. Following this trend of mind on leadership, it was shown that (Bass, 1985; Avolio \& Bass, 1988; Howell \& Avolio, 1993) transformational leaders were charismatic, inspirational, intellectually stimulating, and individually considerate individuals. Charismatic leaders are the ones who are recognized and respected among peers, subordinates and even superiors. They are in every sense the role models whom employees try to emulate and follow indubitably. They create an idealized influence on others. Therefore they, who demonstrate high standards of ethical and moral conduct, can be trusted by employees in order to do right thing (Avolio, 1999: 43). Inspirational leaders are the ones who incite and motivate their subordinates by giving meaning and optimism about the mission. They always show the full part of the mug in all circumstances. By this means they create a positive atmosphere among employees. Intellectually stimulating leaders are the ones who encourage and direct their employees to question the conceded facts from different perspectives. By this means they teach their followers how to catch a fish. Individually considerate leaders are the ones who act as mentors. Namely, they help the ones who are in need of and provide support for their higher-level achievements. As a consequence, transformational leaders who possess all of the aforementioned capabilities motivate their followers to transcend their self-interests and work for the good of the team, the group and the overall organization (Bass et al., 1996: 10; Bass, 1990: 21).

On the other end of the line, there is transactional leadership, of which nature refers to a tradeoff between leader and followers. That is, followers are motivated by the rewards, promotions, premium or other incentives in exchange of success in the job. At the same time, the negative procedures are in use of motivating followers as well, such as, negative feedback, reproof, threats or punishments (Bass \& Steidlmeier, 1999: 184). Despite their distinct definitions, there is an overlap between transformational leadership and transactional leadership. An ideal model of leader applies both leadership types in time of need (Avolio et al., 1999: 457). Namely, transformational leadership strengthens the effectiveness of transactional leadership and both leadership types complement each other (Kanungo \& 
Mendonca, 1996: 53; Bass, 1998: 7). For example in order to empower employees, leaders may apply contingent rewards component of transactional leadership and charisma component of transformational leadership at the same time (Conger \& Kanungo, 1988: 478). Besides, each leadership type has ethical and philosophical components, as a result of which leaders form a moral profile. For example while transformational leaders should behave according to a free and unwritten contract between them and employees, which has to have a moral legitimacy, covering providence of liberty, telling the truth, keeping promises and honesty, transformational leaders should act virtuously, as a role model for followers, depending on values created and morally accepted in order to produce common good (Bass \& Steidlmeier, 1999: 185-186). This connection describes features of a new type of leadership behavior unwittingly: ethical leadership.

According to findings of Trevino et al. (2003: 21), ethical leadership has both transformational and transactional dimensions. That is, ethical leaders are perceived by their followers as receptive, open, honest, people oriented rolemodels, who conduct ethically, fairly and focus on values. At the same time ethical leaders are perceived as the ones who set ethical standards, for which followers are held responsible, have broad ethical awareness, which underlies the ethical decision making processes and care for all the stakeholders. Howell and Avolio (1992: 48) emphasize the importance of moral standards that ethical leaders follow when deciding what is wrong or right, even under circumstances of being contrary to popular expectations of the majority. Trevino et al. (2000: 134) indicated two aspects of ethical leadership: being a moral person and being a moral manager, which brings ethical leaders into prominence in addition to other characteristics as role models to followers, whose discourses and behaviors in private and occupational life are emulated by followers.

In the light of above mentioned researches on ethical leadership and depending on the Bandura's $(1977,1986)$ social learning theory Brown et al. (2005: 119-120) defined ethical leadership. According to social learning theory anything can be learned through direct observation of behaviors and its consequences. This process surely can occur when leaders act as role models, by virtue of their position and roles in the organization. Throughout this process followers can learn what behaviors are rewarded, expected and punished naturally. By engaging in fair, just, caring behaviors toward followers and creating a fair working culture, ethical leaders become the source of ethical conduct and emulation spontaneously (Bandura, 1986: 207). Therefore ethical leadership is defined as the demonstration of normatively appropriate conduct through personal actions and interpersonal relationships, and the promotion of such conduct to followers through two-way communication, reinforcement, and decision-making (Brown et al., 2005: 120). That is, ethical leaders are perceived by their followers as honest, caring and principled role models, who practice what they preach, make balanced decisions and manage fairly. Ethical leaders communicate with their followers about ethical values, set ethical standards, and utilize punishment and reward mechanisms in 
order their followers to internalize those standards as well (Brown \& Trevino, 2006: 597).

\section{Ethical Leadership as A Healer of Employees' Intention to Quit}

The notion of intention to quit refers to employees' decisions about leaving their organizations with conscious and their own will (Sigri \& Cira, 2010: 937). Such feelings of employees occur due to several factors, which generally make wounds in them. Some of the factors that cause employees' intention to quit are; job dissatisfaction, aging, insufficient education, upward mobility (Martin, 1979: 320), job content, stress, degree of autonomy, insufficient and deteriorating leadership, distributive injustice, lack of promotional chances (Griffeth et al., 2000: 483), workplace bullying and downward mobbing (Simons, 2008: 55). Herein ethical leadership may be a cure for the employees who intended to quit their jobs due to aforementioned several reasons. In this context, findings of Elci et al.'s (2012: 295) study clearly support our way of thinking. That is, having collected data from 1093 employees in 70 firms operating in nine different industries including pharmaceuticals, finance, manufacturing, services, health, food, transportation, information technology and construction, they found that ethical leadership is one of significant negative predictors of employees' turnover intention. Likewise Filipova (2009: 15) discovered negative predictive effect of ethical climate on nurses' intention to quit and Shapira-Lishchinsky and Rosenblatt (2009: 21) found the similar effect of ethical climate on teachers' intention to leave. Besides, Wells and Peachey (2010: 32) discovered negative predictive effect of both transactional and transformational leadership types, a synthesis of which form the basis of the ethical leadership, on softball and volleyball assistant coaches' intention to quit. In the light of these studies we posit that nature and essence of the ethical leadership may prevent the formation of the feelings, which lead employees to quit their jobs. Hence we hypothesize:

Hypothesis 1: Ethical leadership negatively predicts the employees' intention to quit.

\section{The Role of Employees' Perceptions of Organizational Politics}

The notion of organizational politics refers to the management of influence to obtain ends not sanctioned by the organization or to obtain sanctioned ends through not-sanctioned influence means (Mayes \& Allen, 1977: 675). Namely, organizational politics describe the intentional and influential behaviors of employees, which are done in order to obtain personal or group interests. Some specific tactics of organizational politics are attacking or blaming others, use of information, impression management and image building, support building for ideas, praising others and ingratiation, setting power coalitions and getting strong allies, associating with the influential people, creating obligations and reciprocity (Allen et al., 1979: 79). Employees generally tend to behave politically when there is a certain amount of ambiguity in work environment, which may be a 
consequence of lack of leadership capabilities. In these circumstances, when employees perceive the organization to be political in nature, they react to it, by quitting their job and leaving the organization, ignoring the political behavior and immersing themselves in their work or becoming a part of political games (Ferris \& Kacmar, 1992: 97). Similarly, according to Ferris et al. (1989: 162) and Kacmar, et al. (1999: 385) if employees perceive organizational politics in working environment and they can't deal with it or don't have control over it, they interpret organizational politics as a threat to their well being, which cause negative outcomes from employees' and organizations' perspective. From this point of view Parker et al. (1995: 906) discovered that employees' perceptions of organizational politics lessen their perceptions of innovation in working environment. Cropanzano et al. (1997: 173) found that employees' perceptions of organizational politics strengthen their feelings about psychological withdrawal and turnover intentions. Kacmar et al. (1999: 400), Vigoda (2000: 339), Huang et al. (2003: 525), Milleret al. (2008: 215), Chang et al. (2009: 792) and Daskin and Tezer, (2012: 283) also discovered considerable predictive effect of perceptions of organizational politics on employees' intention to quit. In the light of these findings it seems that perceptions of organizational politics are one of definite predictors of employees' intention to quit. Therefore we posit that due to its features, even if ethical leadership is not able to prevent the perceptions of organizational politics completely, it may lessen the level of perception. Likewise, findings of Kacmar et al. (2011: 636) indicate negative relationships between ethical leadership and perceptions of organizational politics along with moderating role of organizational politics between ethical leadership and organizational citizenship behaviors. Kacmar et al. (2013: 40) also discovered strong negative predictive effect of ethical leadership on employees' perceptions of organizational politics. However, existence of perceptions of organizational politics may lessen the healing effect of ethical leadership on employees' intention to quit as well. Hence we hypothesize:

Hypothesis 2: Perceptions of organizational politics cause a change in the effect of ethical leadership on employees' intention to quit.

\section{The Role of Employees' Organizational Identification}

Throughout their lives, individuals are frequently in search of an affiliation, with which they can identify themselves (Başar, 2010: 1660). In this context, people form social identities depending on the question of "Who am I?". The social groups such as, the city where being lived, the gender or even the football club, being a fan of which can help people to answer this question (Ashforth \& Mael, 1989: 21). That is, individuals can identify themselves by saying "I am a fan of Galatasaray football club" or "I am a man". In a similar vein, employees tend to identify themselves with their organization. As an aspect of social identity, employees form organizational identities, which answer the question of "Who am I?" as well (Ashforth \& Mael, 1989: 22). With its positive outcomes, in terms of management of organizations, organizational identification is among invaluable attitudes of employees. Because 
employees, who identify themselves with their organization strongly, confront many troubles such as economic crises, lack of sufficient resources or temporarily low wages due to strong affective ties between them and the organization (Van Knippenberg\& Van Schie, 2000: 138; Miller et al., 2000: 629). From this point of view it can be thought that ethical leaders may foster employees' identification with their organization due to their honest, inciting and moral characters, whereby organizations benefit much. In line with this way of thinking Walumbwa et al. (2011: 210) discovered positive predictive effect of ethical leadership on organizational identification along with mediating role of organizational identification between ethical leadership and job performance. Similarly Qi and Ming-Xia (2014: 238) found positive predictive effect of ethical leadership on organizational identification along with mediating role of organizational identification between ethical leadership and employee voice behavior as well. At the same time it may be reasonable to treat organizational identification as one of healers of employees' intention to quit. Because, as mentioned previously organizational identification refers to a strong affective tie between employee and the organization, whereby employees identify themselves. Likewise, findings of Van Dick et al. (2004: 356), Riketta (2005: 364), Cole and Bruch (2006: 598), Mignonac et al. (2006: 486), De Maura et al. (2009: 551) and Mishra and Bhatnagar (2010: 410) indicate that organizational identification negatively predicts employees' intention to quit. Depending on these findings, we posit that organizational identification may serve as a mechanism, through which ethical leadership predicts employees' intention to quit. Hence we hypothesize:

Hypothesis 3: Ethical leadership positively predicts employees' organizational identification.

Hypothesis 4: Organizational identification negatively predicts employees' intention to quit.

Hypothesis 5: Organizational identification specifies how ethical leadership predicts employees' intention to quit.

\section{Method}

\subsection{Research Design}

In this study exploratory research design is used. Depending on the hypotheses, interactions among variables were analyzed. Dependent variable of this research is employees' intention to quit and independent variable is ethical leadership. As presented in Figure 1, moderation effect of perceptions of organizational politics and mediation effect of organizational identification are analyzed as well. 


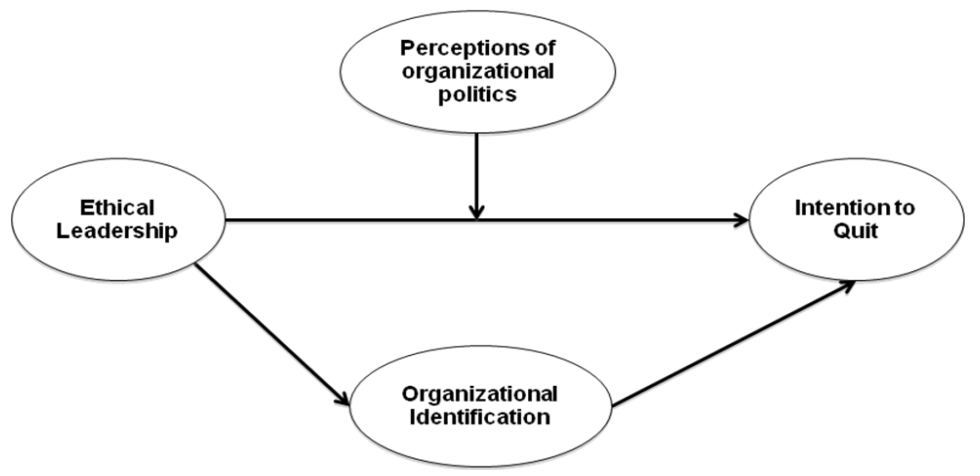

Figure 1. Research Design

\subsection{Participants}

The universe of this research is a total of 103 salespersons of a white good producer, who work in Ankara, Turkey. All of the salespersons participated in this survey upon the request of their sales manager. 79 of the participants $(76.7 \%)$ are males and 24 of them (23.3\%) are females. Ages of the participants vary from 27 to 50 years with an average of 34.61 years $(S D=5.36) .71$ of the participants $(68.9 \%)$ are married and 32 of them (31.1\%) are bachelor. Participants' tenure of office varies from 2 years to 26 years with an average of 9.33 years $(S D=5.77)$. Education level of participants is presented in Table 1.

\section{Table 1: Education Level of Participants}

\begin{tabular}{lll}
\hline Level of Education & $\mathrm{N}$ & $\%$ \\
\hline High School & 2 & 1.9 \\
University & 94 & 91.3 \\
Post Graduate & 7 & 6.8 \\
\hline
\end{tabular}

\subsection{Data Collection Instruments}

\subsubsection{Measure of Ethical Leadership}

Ethical leadership was measured with the questionnaire, which was developed by Brown et al. (2005) and adapted to Turkish by Tuna et al. (2012). Questionnaire consists of 9 items. Five point Likert-type scale ( $1=$ strongly disagree, $5=$ strongly agree) measures ethical leadership within one dimension. Ascending points indicate strength of each item. Reliability of the scale was assessed using Cronbach's coefficient alpha of $\alpha=.95$. Validity of scale was tested with confirmatory factor analysis $(\Delta \times 2=29.79, p=.07, S D=20, \Delta \times 2 / S D=1.49, G F I=.93$, $\mathrm{IFI}=.99, \mathrm{CFI}=.99, \mathrm{RMSA}=.06, \mathrm{CFI}=.99$ ) which verifies its one factor structure. Factor loadings of items vary from .85 to .91 explaining $76.35 \%$ of variance. KMO and Bartlett's Test results are presented in Table 2. Results indicate convenience of factor analysis. 
Table 2: KMO and Bartlett's Test Results-1

\begin{tabular}{ccc}
\hline Kaiser-Meyer-Olkin Measure of Sampling Adequacy. & .91 \\
\hline Bartlett's Test of Sphericity & Approx. Chi-Square & 1033.51 \\
\hline $\mathrm{df}$ & 36 \\
\hline Sig. & .000 \\
\hline
\end{tabular}

\subsubsection{Measure of Intention to Quit}

Intention to quit was measured with the questionnaire, which was developed by Walsh et al. (1985) and adapted to Turkish by Ok (2007). Questionnaire consists of 5 items. Five point Likert-type scale (1=strongly disagree, 5=strongly agree) measures intention to quit within one dimension. Ascending points indicate strength of each item. Reliability of the scale was assessed using Cronbach's coefficient alpha of $\alpha=.92$ Validity of scale was tested with confirmatory factor analysis $(\Delta \chi 2=2.75, \mathrm{p}=.09, \mathrm{SD}=1, \Delta \mathrm{x} 2 / \mathrm{SD}=2.75, \mathrm{GFI}=.98, \mathrm{IFI}=.99, \mathrm{CFI}=.99, \mathrm{CFI}=.99$ ) which verifies its one factor structure. Factor loadings of items vary from .85 to .91 explaining $77.42 \%$ of variance. KMO and Bartlett's Test results are presented in Table 3. Results indicate convenience of factor analysis.

\section{Table 3: KMO and Bartlett's Test Results-2}

\begin{tabular}{ccc}
\hline Kaiser-Meyer-Olkin Measure of Sampling Adequacy. & .74 \\
\hline Bartlett's Test of Sphericity & Approx. Chi-Square & 497.46 \\
\hline df & 10 \\
\hline Sig. & .000 \\
\hline
\end{tabular}

\subsubsection{Measure of Perceptions of Organizational Politics}

Perceptions of organizational politics were measured with the questionnaire, which was developed by Hochwarter et al. (2003) and adapted to Turkish by Akdogan and Demirtaş (2014). Questionnaire consists of 6 items. Five point Likert-type scale (1=strongly disagree, $5=$ strongly agree) measures perceptions of organizational politics within one dimension. Ascending points indicate strength of each item. Reliability of the scale was assessed using Cronbach's coefficient alpha of $\alpha=.95$. Validity of scale was tested with confirmatory factor analysis $(\Delta x 2=9.75, p=.13$, $\mathrm{SD}=6, \Delta \chi 2 / \mathrm{SD}=1.62, \mathrm{GFI}=.97, \mathrm{IFI}=.99, \mathrm{CFI}=.99, \mathrm{RMSA}=.07, \mathrm{CFI}=.99)$ which verifies its one factor structure. Factor loadings of items vary from .89 to .90 explaining $80.31 \%$ of variance. KMO and Bartlett's Test results are presented in Table 4. Results indicate convenience of factor analysis.

\section{Table 4: KMO and Bartlett's Test Results-3}

\begin{tabular}{ccc}
\hline Kaiser-Meyer-Olkin Measure of Sampling Adequacy. & .88 \\
\hline Bartlett's Test of Sphericity & Approx. Chi-Square & 609.28 \\
\hline df & 15 \\
\hline Sig. & .000 \\
\hline
\end{tabular}




\subsubsection{Measure of Organizational Identification}

Organizational identification was measured with the questionnaire, which was developed by Mael and Ashforth (1992), and adapted to Turkish by Tüzün (2006). Questionnaire consists of 6 items. Five point Likert-type scale (1=strongly disagree, $5=$ strongly agree) measures organizational identification within one dimension. Ascending points indicate strength of each item. Reliability of the scale was assessed using Cronbach's coefficient alpha of $\alpha=.94$. Validity of scale was tested with confirmatory factor analysis $(\Delta \chi 2=5.27, \mathrm{p}=.38, \mathrm{SD}=5.27, \Delta \mathrm{\chi} 2 / \mathrm{SD}=1.05, \mathrm{GFI}=.98$, $\mathrm{NFI}=.99, \mathrm{RMSA}=.02$ ) which verifies its one factor structure. Factor loadings of items vary from .85 to .91 explaining $78.16 \%$ of variance. KMO and Bartlett's Test results are presented in Table 5. Results indicate convenience of factor analysis.

\section{Table 5: KMO and Bartlett's Test Results-4}

\begin{tabular}{|c|c|c|}
\hline Kaiser-Meyer-Olkin Measur & ampling Adequacy. & .85 \\
\hline \multirow[t]{2}{*}{ Bartlett's Test of Sphericity } & Approx. Chi-Square & 585.05 \\
\hline & $\mathrm{df}$ & 15 \\
\hline & Sig. & .000 \\
\hline
\end{tabular}

\subsection{Procedure}

In order to conduct this research, an appointment was taken from sales manager of a white good producing international firm. The aim and scope of the survey were explained to the sales manager in person and his permission was taken during the meeting. Later on, sales persons were summoned to central office of the firm in Ankara, Turkey by sales manager on $17^{\text {th }}$ of November, 2014. Upon gathering of all of the sales persons, who are totally 103 persons, a short briefing about the aim and scope of the survey and instructions about filling the questionnaires were given by the first author of this paper. Questionnaires were delivered manually. The ones who filled handed the questionnaire over and left the saloon. Following the collection of the data, reliability and validity analyses of each scale were done. Subsequently, each hypothesis was tested with correlation and regression analyses.

\section{Findings and Discussion}

Findings in Table 6 indicate that participants accept their manager as an ethical leader $(M=4, S D=.83)$ and identify themselves with their organizations $(M=4.06$, $\mathrm{SD}=.90$ ) with a mean score for each variables above average of 2.5 points. In line with these findings participants perceive small amount of politics $(M=2.27, S D=.91)$ and barely intent to quit $(M=1.96, S D=.92)$ their jobs with a mean score below average of 2.5 points.

The correlations between each variable are presented in Table 6. Findings indicate significant correlations between each variable, which allow us to conduct moderation and mediation analyses at further stages. In addition to strong positive relations between ethical leadership and organizational identification $(r=.78$, 
$p<.01$ ), strong negative correlations between ethical leadership, perceptions of organizational politics $(r=-.68, p<.01)$ and intention to quit $(r=-.66, p<.01)$ support our assertion of ethical leadership's healing function. Besides that positive correlations between perceptions of organizational politics $(r=.59, p<.01)$ and intention to quit are remarkable as well.

\section{Table 6: Means, Standard Deviations and Correlation Coefficients}

\begin{tabular}{lcccccc}
\hline Variables & $M$ & $S D$ & 1 & 2 & 3 & 4 \\
\hline 1. EL & 4 & .83 & 1 & & & \\
2. OI & 4.06 & .90 & $.78^{*}$ & 1 & & \\
3. POP & 2.27 & .91 & $-.68^{*}$ & $-.57^{*}$ & 1 & \\
4. IQ & 1.96 & .92 & $-.66^{*}$ & $-.56^{*}$ & $.59^{*}$ & 1 \\
\hline
\end{tabular}

${ }^{*} p<.01$ (EL: Ethical Leadership, OI: Organizational Identification, POP: Perceptions of Organizational Politics, IQ: Intention to Quit)

Results of simple linear regression analysis, presented in Table 7 support our Hypothesis 1, which asserted the existence of a causal relationship between ethical leadership and intention to quit. Interpretation of the findings implies that ethical leaders significantly lessen the development of employees' intention to quit. This finding at the same time affirms the healing effect of ethical leadership on employees' intention to quit. In this respect, except difference in samples, our findings cohere studies of Elci et al. (2012).

\section{Table 7: Ethical Leadership and Intention to Quit}

\begin{tabular}{llccc}
\hline \multirow{2}{*}{ Model } & \multicolumn{3}{c}{ Intention to Quit } \\
\hline \multirow{2}{*}{$\begin{array}{l}\text { Constant } \\
\text { EL }\end{array}$} & $4.93^{*}$ & $\beta$ & $\Delta \mathrm{R}^{2}$ \\
\hline${ }^{*} p<.01$ (EL: Ethical Leadership) & $-.74^{*}$ & $-.66^{*}$ & $.44^{*}$ \\
\hline
\end{tabular}

In order to test Hypothesis 2 we analyzed moderation effect of perceptions of organizational politics. Results of moderation analyses are presented in Table 8.

\section{Table 8: Results of Moderation Analysis}

\begin{tabular}{|c|c|c|c|c|}
\hline \multirow{2}{*}{\multicolumn{2}{|c|}{ Model }} & \multicolumn{3}{|c|}{ Intention to Quit } \\
\hline & & $\mathrm{B}$ & $\beta$ & $\Delta \mathrm{R}^{2}$ \\
\hline \multirow[t]{3}{*}{1} & Constant & -7.85 & & \multirow{3}{*}{$.47^{* *}$} \\
\hline & $\mathrm{EL}$ & $-.48 * *$ & $-.48 * *$ & \\
\hline & POP & $.26^{*}$ & $.26^{*}$ & \\
\hline \multirow[t]{4}{*}{2} & Constant & -.96 & & \multirow{4}{*}{$.49 *$} \\
\hline & EL & $-.32^{*}$ & $-.32 *$ & \\
\hline & POP & $.30 *$ & $.30 *$ & \\
\hline & EL X POP & $-.14 *$ & $-.21 *$ & \\
\hline
\end{tabular}


Findings indicate a significant moderation effect of perceptions of organizational politics over ethical leadership's negative predictive effect on intention to quit, which is a new discovery. That is, before entering the moderator variable (ELXPOP) ethical leadership has a negative predictive effect of $(\beta=-.48, p<.01)$ on intention to quit. However after entering the moderator variable, effect of ethical leadership lessens $(\beta=-.32, p<.05)$ significantly.

That means perceptions of organizational politics cause a change in magnitude of ethical leadership's predictive effect on intention to quit, which supports Hypothesis 2. As presented in Figure 1. depending on the strength of the perceptions of organizational politics, ethical leadership's effect on intention to quit changes. Namely, as strength of perceptions of organizational politics increase, ethical leadership's effect on intention to quit decreases. This new discovery implies that perceptions of organizational politics overshadow ethical leaders' charming power over employees by diminishing its healing function.

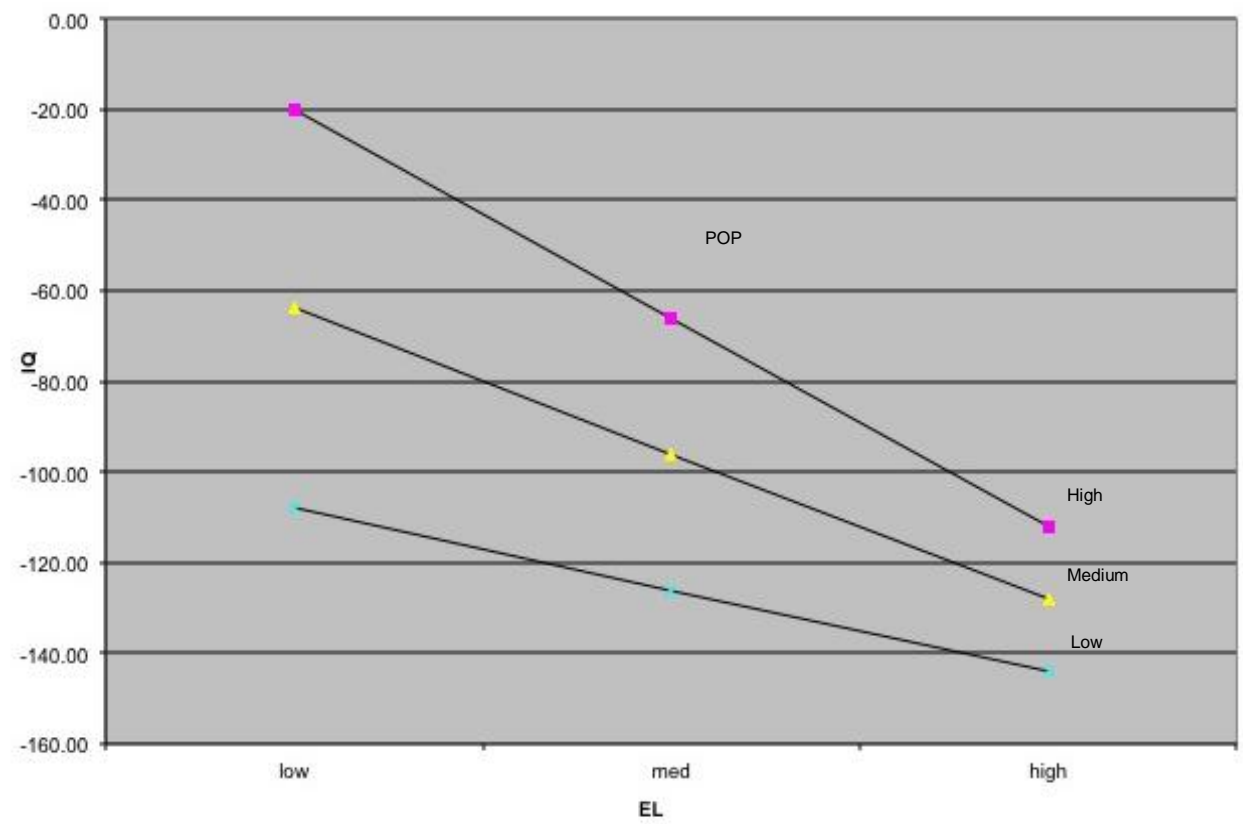

Figure 1: Moderation Effect of POP

(EL: Ethical Leadership, IQ: Intention to Quit, POP: Perceptions of Organizational Politics)

However findings, presented in Table 9 indicate that ethical leadership significantly lessens emergence of perceptions of organizational politics $(\beta=-.68, p<.01)$, which empowers ethical leaders' healing function. This intriguing finding accord with findings of Kacmar et al. (2013) as well. 


\section{Table 9. Ethical Leadership and Perceptions of Organizational Politics}

\begin{tabular}{lllll}
\hline \multirow{2}{*}{ Model } & \multicolumn{4}{c}{ Perceptions of Organizational Politics } \\
& $\mathrm{B}$ & $\beta$ & $\Delta \mathrm{R}^{2}$ \\
\hline $1 \quad$ Constant & $5.30^{*}$ & & \multirow{2}{*}{$.46^{*}$} \\
& $\mathrm{EL}$ &.$-75^{*}$ & $-.68^{*}$ & \\
\hline${ }^{*} p<.01$ (EL: Ethical Leadership) & &
\end{tabular}

In order to analyze mediation effect of organizational identification, initially we measured ethical leadership's effect on organizational identification. As presented in Table 10, findings indicate significant causal relationships between ethical leadership and organizational identification $(\beta=.78, p<.01)$, which accord with findings of Walumbwa et al. (2011) and Qi and Ming-Xia (2014) and support Hypothesis 3. This means ethical leaders inspire their followers to identify themselves with their organization by strengthening their affective ties. This result may be interpreted as a consequence of ethical leaders' charismatic, dependable and caring character and a part of healing function of ethical leadership.

\section{Table 10: Ethical Leadership and Organizational Identification}

\begin{tabular}{|c|c|c|c|c|}
\hline \multirow{2}{*}{\multicolumn{2}{|c|}{ Model }} & \multicolumn{3}{|c|}{ Organizational Identification } \\
\hline & & B & $\beta$ & $\Delta \mathrm{R}^{2}$ \\
\hline 1 & $\begin{array}{l}\text { Constant } \\
\text { EL }\end{array}$ & $\begin{array}{l}.65^{* *} \\
.85^{*}\end{array}$ & $.78 *$ & $.61^{*}$ \\
\hline
\end{tabular}

${ }^{*} p<.01,{ }^{* *} p<.05$ (EL: Ethical Leadership)

As another step of mediation analysis, we measured organizational identification's effect on intention to quit. Findings, which are presented in Table 11, indicate significant causal relationships between organizational identification and intention to quit $(\beta=-.56, p<.01)$. Results support Hypothesis 4 and accord with findings of Van Dick, et al. (2004), Riketta (2005), Cole and Bruch (2006), Mignonac et al. (2006), De Maura et al. (2009) and Mishra and Bhatnagar (2010). These findings may be interpreted as a part of our proposed healing framework. Namely, employees, who strongly identify themselves with their organization don't tend to quit their jobs. In this context factors, which cause organizational identification, may be treated as healers as well.

\section{Table 11: Organizational Identification and Intention to Quit}

\begin{tabular}{|c|c|c|c|}
\hline \multirow{2}{*}{ Model } & \multicolumn{3}{|c|}{ Intention to Quit } \\
\hline & B & $\beta$ & $\Delta \mathrm{R}^{2}$ \\
\hline Constant & $4.30^{*}$ & & \multirow{2}{*}{$.31 *$} \\
\hline $\mathrm{OI}$ & $-.57^{*}$ & $-.56 *$ & \\
\hline
\end{tabular}

${ }^{*} p<.01$ (OI: Organizational Identification)

The last step of mediation analysis is entering both organizational identification and ethical leadership at the same time into the multiple linear regression analysis as 
independent variables of research model. Findings, which are presented in Table 12 , indicate that there is no mediation effect of organizational identification between ethical leadership and intention to quit. That's why Hypothesis 5 is not supported. When two independent variables are entered into the analysis at the same time, the path between ethical leadership and intention to quit remained significant $(\beta=-.59, p<.01)$, however the path between organizational identification and intention to quit changed to insignificant $(\beta=-.09, p>.05)$, which is a proof of inexistence of mediation effect of organizational identification. This is another new discovery of our research. That is, both ethical leadership and organizational identification are positive predictors of intention to quit, however organizational identification doesn't specify how ethical leadership predicts intention to quit. In other words ethical leaders cause employees to keep up with their organizations and jobs not through organizational identification. Each variable, organizational identification and ethical leadership predicts intention to quit independently.

Table 12: Results of Mediation Analysis

\begin{tabular}{|c|c|c|c|c|}
\hline \multirow{2}{*}{\multicolumn{2}{|c|}{ Model }} & \multicolumn{3}{|c|}{ Intention to Quit } \\
\hline & & B & $\beta$ & $\Delta R^{2}$ \\
\hline \multirow{3}{*}{1} & Constant & $5.00 *$ & & \\
\hline & OI & -.10 & -.09 & $.44 *$ \\
\hline & EL & $-.65^{*}$ & $-.59 *$ & \\
\hline
\end{tabular}

\section{Conclusion}

According to our findings ethical leaders can heal the wounds. Namely, ethical leaders can create an ethical climate, in which employees may recover from several troubles and their wounds may be healed. The troubles that employees deal with may derive from both personal and organizational factors and later on may cause deep wounds. That is, performance loss and low morale of employees may derive from an incurable disease, interfamilial problems or organizational issues such as, conflicts with superiors, peers or subordinates, which at the end may drag employees to the brink of quitting their job (Dutton et al., 2002: 55). In this context, findings of this research help understanding this process and the role of ethical leaders in recovery of employees.

The aim of this research was to find out predictive effect of ethical leadership on employees' intention to quit along with the moderation effect of perceptions of organizational politics and mediation effect of organizational identification on this process, within metaphorical healing framework. As distinct from previous studies, to the best of our knowledge the moderation effect of perceptions of organizational politics on ethical leadership's prediction on intention to quit was discovered for the first time. According to the findings, although ethical leaders lessen the occurrence of perceptions of organizational politics, it still continues to 
diminish predictive effect of ethical leaders on employees' intention to quit negatively. In addition, it was discovered that when analyzed at the same time, organizational identification and ethical leadership predict intention to quit independently. In other words organizational identification doesn't specify or explain how ethical leadership predicts intention to quit. As far as we know this is another new discovery. Occurrence of this independency may derive from strong direct effect of ethical leaders on employees toward not to quit their jobs beyond organizational identification, which may be a consequence of dependable, honest, reliable and convincing character of ethical leaders.

Despite its remarkable findings, our study have some limitations as well, one of which is the scarcity of previous studies on research topic. If there had been prior studies, we could have compared our findings with theirs. Additionally, the oneness of our sample is another limitation. That is, if we had collected data from other samples too, such as from salespersons of other firms or participants who belong to other occupations, we could have compared the results of each survey. Finally we collected data solely by means of questionnaire, which limits participants' ideas about research topic to questionnaire items and answer choices. If we had used qualitative data collection methods too, we could have interpreted findings together and understood participants' ideas better.

Finally, it may be concluded that if the role of ethical leaders in prosperity of organizations and employees was comprehended by practitioners in terms of their healing and inspiring effect, a good many of organizational problems such as economic turbulences or managerial crises and personal issues would be solved. Therefore we believe that managers should pay attention to findings of this study. Managers of any type of organizations should internalize and put into action the principles of ethical leadership. By this means organizations may prevent unexpected resignations of employees to some extent, avoid politics in work places and encourage employees to identify themselves with their organization. Ethical character of leaders would shape organizational climate and create an ethical working atmosphere in which employees may satisfy more. Thereby employees may less tend to use politics. Moreover this study may shed more light for future surveys, by showing potential research areas about ethical leadership and perceptions of organizational politics. Namely, future researches may be conducted on ethical leadership and its predictive effect on other variables such as, employees' neglect, psychological withdrawal, absenteeism or burnout where moderation role of perceptions of organizational politics in this process may be analyzed as well. Besides that ethical leadership's effects on psychological harassments toward employees such as, downward mobbing and work place bullying can be researched within metaphorical framework of ethical leadership's healing role. 


\section{References}

Akdogan, A., \& Demirtas, O. (2014) "Etik liderlik davranışlarının etik iklim üzerindeki etkisi: örgütsel politik algılamaların aracılık rolü" Journal of Economics and Administrative Sciences 16(1): 103-120.

Allen, R.W., Madison, D.L., Porter, L. W., Renwick, P. A. \& Mayes, B. T. (1979) “Organizational politics tactics and characteristics of its actors" California Management Review 12(1): 7783.http://dx.doi.org/10.2307/41164852

Ashforth, B. E., and Mael, F. (1989) Social identity theory and the organization. Academy of Management Review 14(1), 20-39.

Avolio, B. J. (1999) Full Leadership development: building the vital forces in organizations. Thousand Oaks, CA: Sage.

Avolio, B. J., and Bass, B. M. (1988) "Transformational leadership, charisma and beyond" In G. Hunt, B. R. Balaga, H. P. Dachler, \& C. Schriesheim (Eds.), Emerging Leadership Vistas pp. 29-50 Elmsford, NY: Pergamon Press.

Avolio, B. J., Bass, B. M., \& Jung, D. I. (1999) "Re-Examining the components of transformational and transactional leadership using the multifactor leadership questionnaire" Journal of Occupational and Organisational Psychology 72: 441 462.http://dx.doi.org/10.1348/096317999166789

Aydemir, M. \& Egilmez, O. (2010) "An important antecedent of ethical / unethical behavior: religiosity" Eurasian Journal of Business and Economics 3(6): 71-84.

Bandura, A. (1977) Social learning theory. Englewood Cliffs, NJ: Prentice-Hall.

Bandura, A. (1986) Social foundations of thought and action. Englewood Clifs, NJ: PrenticeHall

Bass, B. M. (1985) Leadership and performance beyond expectations. New York: Free Press.

Bass, B. M. (1990) Bass \&Stogdill's handbook of leadership. New York: The Free Press

Bass, B. M. (1998) Transformational leadership: industrial, military and educational impact. Mahwah, NJ: Erlbaum.

Bass, B. M., Avolio, B. J., \& Atwater, L. (1996) "The transformational and transactional leadership of men and women" Applied Psychology: An International Review 45(1): 5 34.http://dx.doi.org/10.1111/j.1464-0597.1996.tb00847.x

Bass, B. M., \&Steidlmeier, P. (1999) "Ethics, character, and authentic transformational leadership behavior" Leadership Quarterly 10(2): 181-217.http://dx.doi.org/10.1016/S10489843(99)00016-8

Basar, U. (2010). "Örgütlerde çalışanların kişilik özelliklerinin örgütselözdeşleşme düzeylerine olan etkisi: kamu sektöründe bir uygulama", Proceeding presented at International $8^{\text {th }}$ Knowledge, Economy \&Management Congress, Istanbul, Turkey.

Brown, M. E., Trevino, L. K. \& Harrison, D. A. (2005) "Ethical leadership: a social learning perspective for construct development and testing" Organizational Behavior and Human Decision Processes 97: 117-134.http://dx.doi.org/10.1016/i.obhdp.2005.03.002

Brown, M. E., \& Trevino, L. K. (2006) "Ethical leadership: a review and future directions" The Leadership Quarterly 17: 595-616.http://dx.doi.org/10.1016/j.leaqua.2006.10.004

Buell, J. M. (2012) "Defining leadership behavioral competencies for success" Healthcare Executive: 19-26. 
Burns, J. M. (1978) Leadership. New York: Harper Row.

Chang, C., Rosen, C. C., \& Levy, P. E. (2009) "The relationship between perceptions of organizational politics and employee attitudes, strain, and behavior: a meta-analytic examination" Academy of Management Journal 52(4): 779801.http://dx.doi.org/10.5465/AMJ.2009.43670894

Cole, M. S. \& Bruch, H. (2006) "Organizational identity strength, identification, and commitment and their relationships to turnover intention: does organizational hierarchy matter?" Journal of Organizational Behaviour 27:585-605. http://dx.doi.org/10.1002/job.378 Conger, J. A., \& Kanungo, R. N. (1988) "The empowerment process: integrating theory and practice" Academy of Management Review 13(3): 471-482.

Cropanzano, R., Howes, J. C., Grandey, A. A., \& Toth, P. (1997) "The relationship of organizational politics and support to work behaviors, attitudes, and stress" Journal of Organizational Behavior 18: 159-180.http://dx.doi.org/10.1002/(SICI)10991379(199703)18:2<159::AID-JOB795>3.0.CO;2-D

Daskin, M., \&Tezer, M. (2012) “Organizational politics and turnover: an empirical research from hospitality industry" Tourism 60(3): 273-291.

De Maura, G. R., Abrams, D., Retter, C., Gunnarsdottir, S., \& Ando, K. (2009) “Identification as an organizational anchor: how identification and job satisfaction combine to predict turnover intention" European Journal of Social Psychology 39: 540557.http://dx.doi.org/10.1002/ejsp.553

Dutton, E., Frost, P. J., Worline, M. C., Lilius, J. B., \& Kanov, J. M. (2002) "Leading in times of trauma" Harvard Business Review, Jan., 54-61. Reprinted in Harvard Business Review on Building Personal and Organizational Resilience pp. 19-38, 2003. Boston: Harvard Business School Press.

Elci, M., Sener, I.., Aksoy, S., \& Alpkan, L. (2012) "The impact of ethical leadership and leadership effectiveness on employees' turnover intention: the mediating role of work related stress" Procedia - Social and Behavioral Sciences 58: 289-297. http://dx.doi.org/10.1016/i.sbspro.2012.09.1003

Ferris, G. R., \& Kacmar, K. M. (1992) "Perceptions of organizational politics". Journal of Management 18(1): 93-116.http://dx.doi.org/10.1177/014920639201800107

Ferris, G. R., Russ, G. S., \& Fandt, P. M. (1989) “Politics in organizations", In R. A. Giacalone \& P. Rosenfeld (Eds.) Impression Management in The Organization pp. 143-170 Hillside, NJ: Erlbaum.

Filipova, A. A. (2009) "Relationships among ethical climates, perceived organizational support, and Intent-to-Leave for Licensed Nurses in Skilled Nursing Facilities" Journal of Applied Gerontology 20(10): 1-23.

Ford, D. L. \& Ismail, K.N. (2008). "Perceived leader effectiveness across organizational roles: exploratory evidence from central eurasia." Eurasian Journal of Business and Economics 1(2): 131-156.

Griffeth, R. W., Hom, P. W., \& Gaertner, S. (2000) "A meta-analysis of antecedents and correlates of employee turnover: update, moderator tests, and research implications for the next millennium" Journal of Management 26(3): 463488.http://dx.doi.org/10.1177/014920630002600305

Hochwarter, W. A., Kacmar, C., Perrewe, P. L., \& Johnson, D. (2003) "Perceived organizational support as a mediator of the relationship between politics perceptions and 
Ufuk BASAR \& Berrin FILIZOZ

work outcomes" Journal of Vocational Behavior 63: 438456.http://dx.doi.org/10.1016/S0001-8791(02)00048-9

Howell, J. M., \& Avolio, B. J. (1992) "The ethics of charismatic leadership: submission or liberation?"Academyof Management $\quad$ Executive 6(2): 54.http://dx.doi.org/10.5465/AME.1992.4274395

Howell, J. M., \& Avolio, B. J. (1993) "Transformational leadership, transactional leadership, locus of control and support for innovation: key predictors of consolidated business unit performance" Journal of Applied Psychology 78: 891-902.http://dx.doi.org/10.1037/0021$\underline{9010.78 .6 .891}$

Huang, I., Chuang, C. J., \& Lin H. (2003) The role of burnout in the relationship between perceptions of organizational politics and turnover intentions. Public Personnel Management 32(4): 519-531.

Jordan, J., Brown, M. E., Trevino, L. K., \& Finkelstein, S. (2013) "Someone to look up to: executive-follower ethical reasoning and perceptions of ethical leadership" Journal of Management 39(3): 660-683.http://dx.doi.org/10.1177/0149206311398136

Kacmar, K. M., Bozeman, D. P., Carlson, D. S., \& Anthony, W. P. (1999) "An examination of the perceptions of organizational politics model: replication and extension" Human Relations 52(3): 383-416.http://dx.doi.org/10.1177/001872679905200305

Kacmar, K. M., Bachrach, D. G., Harris, K. J., \& Zivnuska, S. (2011) “Fostering good citizenship through ethical leadership: exploring the moderating role of gender and organizational politics" Journal of Applied Psychology 96(3): 633-642.http://dx.doi.org/10.1037/a0021872

Kacmar, K. M., Andrews, M. C., Harris K. J., \& Tepper B. J. (2013) "Ethical leadership and subordinate outcomes: the mediating role of organizational politics and the moderating role of political skill” Journal of Business Ethics 115: 33-44. http://dx.doi.org/10.1007/s10551$\underline{012-1373-8}$

Kanungo, R. N., \& Mendonca, M. (1996) Ethical dimensions in leadership. Beverly Hills, CA: Sage Publications.

Keskes, I. (2014) "Relationship between leadership styles and dimensions of employee organizational commitment: a critical review and discussion of future directions" Intangible Capital 10(1): 26-51. http://dx.doi.org/10.3926/ic.476

Mael, F., \& Ashforth, B. E. (1992) "Alumni and their alma mater: a partial test of the reformulated model of organizational identification" Journal of Organizational Behavior 13: 103-123. http://dx.doi.org/10.1002/iob.4030130202

Martin, T. N. (1979) "A contextual model of employee turnover intentions" Academy of Management Journal 22(2): 313-324.http://dx.doi.org/10.2307/255592

Mayes, B. T., \& Allen, R. W. (1977) "Toward a definition of organizational politics" Academy of Management Review 2(4): 672-678.

McShane, S. L., \&Glinow, M. A. (2009) Organizational Behavior. Boston: McGraw-Hill.

Mignonac, K., Herrbach, O., \& Guerrero, S. (2006) "The interactive effects of perceived external prestige and need for organizational identification on turnover intentions" Journal of Vocational Behavior 69: 477-493.http://dx.doi.org/10.1016/i.jvb.2006.05.006

Miller, B. K., Rutherford, M. A., \& Kolodinsky, R. W. (2008) "Perceptions of organizational politics: a meta-analysis of outcomes" Journal of Business Psychology 22: 209222.http://dx.doi.org/10.1007/s10869-008-9061-5 
Miller, V. D., Allen, M., Casey, M. K., \& Johnson, J. R. (2000) "Reconsidering the organizational identification questionnaire" Management Communication Quarterly 13(4): 626-658.http://dx.doi.org/10.1177/0893318900134003

Mishra, S. K., \& Bhatnagar, D. (2010) "Linking emotional dissonance and organizational identification to turnover intention and emotional well-being: a study of medical representatives in India" Human Resources Management 49(3): 401419.http://dx.doi.org/10.1002/hrm.20362

Ok, B. (2007) Correlates of organizational commitment: A special emphasis on organizational communication. (Unpublished Doctoral Dissertation). Middle East Technical University, Department of Psychology, Ankara, Turkey.

Parker, C. P., Dipboye, R. L., \& Jackson, S. L. (1995) "Perceptions of organizational politics: an investigation of antecedents and consequences". Journal of Management 21(5): 891912.http://dx.doi.org/10.1177/014920639502100505

Qi, Y., \& Ming-Xia, L. (2014) "Ethical leadership, organizational identification and employee voice: examining moderated mediation process in the chinese insurance industry" Asia Pacific Business Review 20(2): 231-248.http://dx.doi.org/10.1080/13602381.2013.823712

Riketta, M. (2005) "Organizational identification: a meta-analysis" Journal of Vocational Behavior 66: 358-384.http://dx.doi.org/10.1016/i.jvb.2004.05.005

Shapira-Lishchinsky, O., \& Rosenblatt, Z. (2009) “Organizational ethics and teachers' intent to leave: an integrative approach" Educational Administration Quarterly 20(10): 134.http://dx.doi.org/10.1177/0013161x09347340

Sigri, U.,\& Cira, A. (2010, October). "Örgütsel vatandaşık davranışlarının (ÖVD) işten ayrılma niyeti üzerine etkisinin incelenmesi", Proceeding presented at International $8^{\text {th }}$ Knowledge, Economy \& Management Congress, Istanbul.

Simons, S. (2008) "Workplace bullying experienced by Massachusetts registered nurses and the relationship to intention to leave the organization" Advances in Nursing Science 31(2): 48-59.http://dx.doi.org/10.1097/01.ANS.0000319571.37373.d7

Trevino, L. K., Brown, M., \& Hartman, L. P. (2003) "A qualitative investigation of perceived executive ethical leadership: perceptions from inside and outside the executive suite" Human Relations 56(1): 5-37.http://dx.doi.org/10.1177/0018726703056001448

Trevino, L. K., Hartman, L. P., \& Brown, M. (2000) "Moral person and moral manager: how executives develop a reputation for ethical leadership" California Management Review 42(4): 128-142. http://dx.doi.org/10.2307/41166057

Tuna, M., Bircan, H., \& Yesiltas, M. (2012) “Etik liderlik ölçeğinin geçerlilik ve güvenilirlik çalışması: Antalya örneği” Atatürk Üniversitesi İktisadi ve İdari Bilimler Dergisi 26(2): 143155.

Tuzun, I. K. (2006) Örgütsel güven, örgütsel kimlik ve örgütsel özdeslesme iliskisi: uygulamalı bir çalısma. (Unpublished Doctoral Dissertation). Gazi Üniversitesi Sosyal Bilimler Enstitüsü, Ankara, Turkey.

Van Dick, R., Christ, O., Stellmacher, J., Wagner, U., Ahlswedew, O., Grubbaw, C., Hauptmeier, M., Höhfeld, C., Moltzen, K., \& Tissington, P. A. (2004) "Should I stay or should I go? explaining turnover intentions with organizational identification and job satisfaction" British Journal of Management 15: 351-360.http://dx.doi.org/10.1111/j.14678551.2004.00424.x 
Van Knippenberg, D., \& Van Schie, E. C. M. (2000) "Foci and correlates of organizational identification" Journal of Occupational and Organizational Psychology 73: 137147.http://dx.doi.org/10.1348/096317900166949

Vigoda, E. (2000) “Organizational politics, job attitudes, and work outcomes: exploration and implications for the public sector" Journal of Vocational Behavior 57: 326-347. http://dx.doi.org/10.1006/ivbe.1999.1742

Walumbwa, F. O., Mayer, D. M., Wang, P., Wang, H., Workman K., \& Christensen, A. L. (2011) "Linking ethical leadership to employee performance: the roles of leader-member exchange, self-efficacy, and organizational identification" Organizational Behavior and Human Decision Processes 115: 204-213.http://dx.doi.org/10.1016/i.obhdp.2010.11.002

Walsh, J. P., Ashford, S. J., \& Hill, T. E. (1985) "Feedback obstruction: the influence of the information environment on employee turnover intentions" Human Relations 38(1): 2346.http://dx.doi.org/10.1177/001872678503800102

Wells, J. E., \& Peachey, J. W. (2010) "Turnover intentions do leadership behaviors and satisfaction with the leader matter?" Team Performance Management 17(1): 23-40. 